\title{
Short Communication / Nota Científica Land of the Giants. Remarkable botanical findings highlight a new area for conservation in Brazil
}

\author{
Renato Mello-Silva ${ }^{1,2}$
}

\begin{abstract}
The finding of Vellozia gigantea in an isolated Campo Rupestre massif within the Mata Atlântica Domain is a remarkable discovery that adds considerable conservation importance to the Serra do Padre Ângelo and Serra da Aliança, in the Doce River valley, Minas Gerais state, Brazil.

Key words: Campo Rupestre, Mata Atlântica, Serra do Padre Ângelo, Serra da Aliança, Vellozia gigantea.

Resumo

A ocorrência de Vellozia gigantea num maciço isolado de campo rupestre no domínio da Mata Atlântica, no vale do rio Doce em Minas Gerais, é uma descoberta notável que acrescenta importância considerável à conservação da Serra do Padre Ângelo e da Serra da Aliança.

Palavras-chave: Campo Rupestre, Mata Atlântica, Serra do Padre Ângelo, Serra da Aliança, Vellozia gigantea.
\end{abstract}

The discovery of Vellozia gigantea N.L.Menezes \& Mello-Silva (Mello-Silva \& Menezes 1999) was a remarkable event. This 6-m tall dracenoid monocot is not only the largest species of the family Velloziaceae, but also has been recognised as an endemic and emblematic species of the Serra do Cipó, a rich biodiverse area in the Espinhaço Range of Minas Gerais State, central Brazil (Fig. 1a,b). Now, V. gigantea is a flagship species of the Serra do Cipó National Park and of the Campo Rupestre archipelago (Prance 1994). Vellozia gigantea is a vulnerable species of a narrow known distribution that covers approximately 150 $\mathrm{km}^{2}$ of disturbed area, where nine populations are divided into three geographical groups presenting different gene pools (Lousada et al. 2011).

Recently, another thrilling botanical discovery, that of the giant Drosera magnifica Rivadavia \& Gonella (Gonella et al. 2015), the largest sundew of the Americas, called attention to the Serra do Padre Ângelo (Fig. 1c). This mountain is part of an isolated quartzitic sandstone massif situated in the municipality of Conselheiro
Pena, $215 \mathrm{~km}$ E of Serra do Cipó, around the very same parallel of $19^{\circ} 18^{\prime} \mathrm{S}$. This massif also includes the mountains of the Sete Salões State Park, in the municipalities of Resplendor and Santa Rita do Itueto, and the Serra da Aliança, in the municipality of Alvarenga. These mountains, which reach $1520 \mathrm{~m}$ above sea level, are the most oriental outposts of the Campo Rupestre in Minas Gerais State (Fig. 1a,b). The phytophysiognomy of these mountains is similar to that of the Espinhaço Range and, like many Campo Rupestre sites, they are home to their share of endemics and rarities. Among others, Alcantarea nana Leme (Leme et al. 2014), Cattleya alvarenguensis (Campacci) Van den Berg (Campacci 2014; Van den Berg 2014), Cattleya munchowiana (F.E.L.Miranda) Van den Berg (Miranda 1999; Van den Berg 2008), Chresta filicifolia Siniscalchi \& Loeuille (Siniscalchi et al. 2016), Embernagra longicauda Strickland (1844, Lopes et al.2016), Eremanthus ovatifolius Loeuille \& Pirani (2016), and Drosera magnifica are examples of biological richness and particularity.

\footnotetext{
${ }^{1}$ Universidade de São Paulo, Depto. Botânica, R. do Matão 277, Sobre-as-Ondas, 05508-090, São Paulo, SP, Brazil.

${ }^{2}$ Author for correspondence: mellosil@usp.br
} 

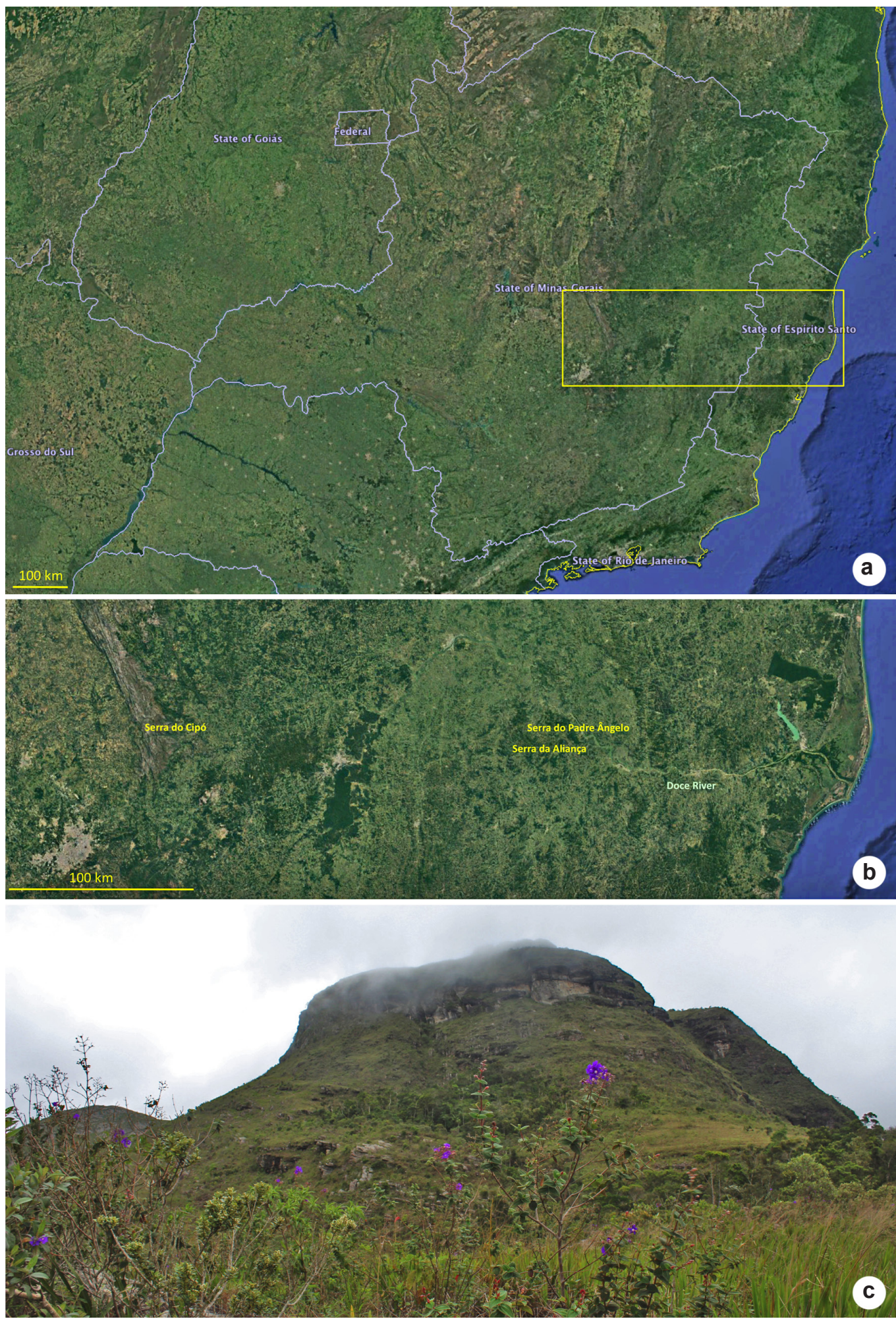

Figure 1 - a. Section of the map of Brazil containing the states of Minas Gerais and Espírito Santo (among others) - the region between Serra do Cipó and the massif of Serra do Padre Ângelo (Serra da Aliança is highlighted); b. detail of the region between Serra do Cipó and Serra do Padre Ângelo - Serra da Aliança Massif, in Rio Doce Valley; c. Serra do Padre Ângelo. (a,b. from Google maps; c. by J. Lopes). 
The implications for the biogeography of the Campo Rupestre biota are noteworthy (Siniscalchi et al. 2016) because, unlike most Campo Rupestre mountains, which are found either within Caatinga and Cerrado Domains, or in the boundaries of the Mata Atlântica and Cerrado, these mountains lie completely within the Mata Atlântica Domain, in a region dominated by granitc inselbergs (Nalini Jr. et al. 2005) and "mar de morros" in the Doce River valley. Its basin was once covered by lush vegetation (Wied-Neuwied 1820; Saint-Hilaire 1830), now almost completely destroyed. It has also been the place of recent environmental tragedy (e.g., Meira et al. 2016; Nazareno \& Vitule 2016; The Guardian 2016).

The Serra do Padre Ângelo has just recently been found by botanists. Many of them, who have been guided by members of the local family Caetano Ribeiro, were amazed by the presence of a huge Velloziaceae in the area. Representatives of this species reach up to six or more meters in height, and the populations occupy considerable areas, comprising thousands of individuals, including numerous seedlings. This notable species, in a recent visit, showed to be Vellozia gigantea (Mello-Silva 4033, K, RB, SPF, US, Fig. 2a-c; Siniscalchi 2024, SPF, Fig. 2f)! It is also present in the contiguous Serra do Pinhão (Danúbia Ribeiro, personal communication) and in the nearby Serra da Aliança (Lopes et al. 2016, Fig. 2e). This unexpected disjunction of a species previously considered endemic to the Serra do Cipó illustrates the very high degree of endemism of the Velloziaceae, whose members usually grow in places which are difficult to get at and little known botanically (Mello-Silva 1991), and adds considerable conservation importance to the Serra do Padre Ângelo and Serra da Aliança. Even more because, although numerous, the populations of $V$. gigantea suffer intense predation by the local people, who use their stems as fuel in wood burning stoves (Danúbia and Paulo Ribeiro, personal communication).

Flagship species and biodiversity richness have frequently been used to support the establishment of conservation units or natural reserves. For example, the presence of Vellozia gigantea in the Serra do Cipó, and the endemic status of many other noteworthy species, such as Coccoloba cereifera Schwacke (1898, Polygonaceae) and Paepalanthus bromelioides Silveira (1908, Eriocaulaceae), as well the exuberance of its flora (Giullietti et al. 1987), were used to justify the establishment of the Serra do Cipó National Park (ICMBio 2009). Similarly, the richness of the flora from Grão Mogol with several endemic species (Pirani et al. 2003) helped to make the case for the recognition of the State Park of Grão Mogol (Fonseca \& Lessa 2010 ), and the discovery of the mono-carvoeiro or muriqui-do-norte (Brachyteles hypoxanthus Wied-Neuwied, 1820), the biggest primate from Americas, living in the luxuriant montane Atlantic Forest of the Serra do Brigadeiro, Minas Gerais, was the urgency for the creation of a State Park (IEF 2007). Thus, the territory of Serra do Padre Ângelo and Serra da Aliança, this land of the giants, deserves conservation not only for harbouring remarkable and vulnerable species of the Campo Rupestre Flora, distant from its core zone, but also for being a yet conserved spot left in a region that has lost almost all of its original natural covering.

\section{Acknowledgments}

To Danúbia, Edmilson, Eva, Júlio, and Paulo Caetano Ribeiro, for their warm welcome and to guide us to the Serra do Padre Ângelo. To Bráulio Marçal, Leonardo Lopes, and Carolina Siniscalchi, for alerting us for the presence of a huge Vellozia in the Serra. To Eimear Nic Lughadha and an anonymous reviewer, for improving the text. The author is CNPq research fellow.

\section{References}

Campacci MA(2014) Hoffmannseggella alvarenguensis Campacci sp. nov. Coletânea de orquídeas brasileiras: novas espécies e híbridos naturais 10 : 382-385.

Fonseca DSR \& Lessa SN (2010) Um breve diagnóstico ambiental do Parque Estadual de Grão Mogol (MG) e seu contexto espacial. Caminhos de Geografia 11: $260-274$.

Giulietti AM, Menezes NL, Pirani JR, Meguro M \& Wanderley MGL (1987) Flora da Serra do Cipó, Minas Gerais: caracterização e lista das espécies. Boletim de Botânica da Universidade de São Paulo 9: 1-151.

Gonella PM, Rivadavia F \& Fleischmann A (2015) Drosera magnifica (Droseraceae): the largest New World sundew, discovered on Facebook. Phytotaxa 220: 257-267.

ICMBio (2009) Plano de Manejo do Parque Nacional da Serra do Cipó e Área de Proteção Ambiental Morro da Pedreira. Instituto Chico Mendes de Conservação da Biodiversidade, Brasília. 102p.

IEF (2007) Plano de Manejo do Parque Estadual da Serra do Brigadeiro. Instituto Estadual de Florestas, Belo Horizonte. 90p. 

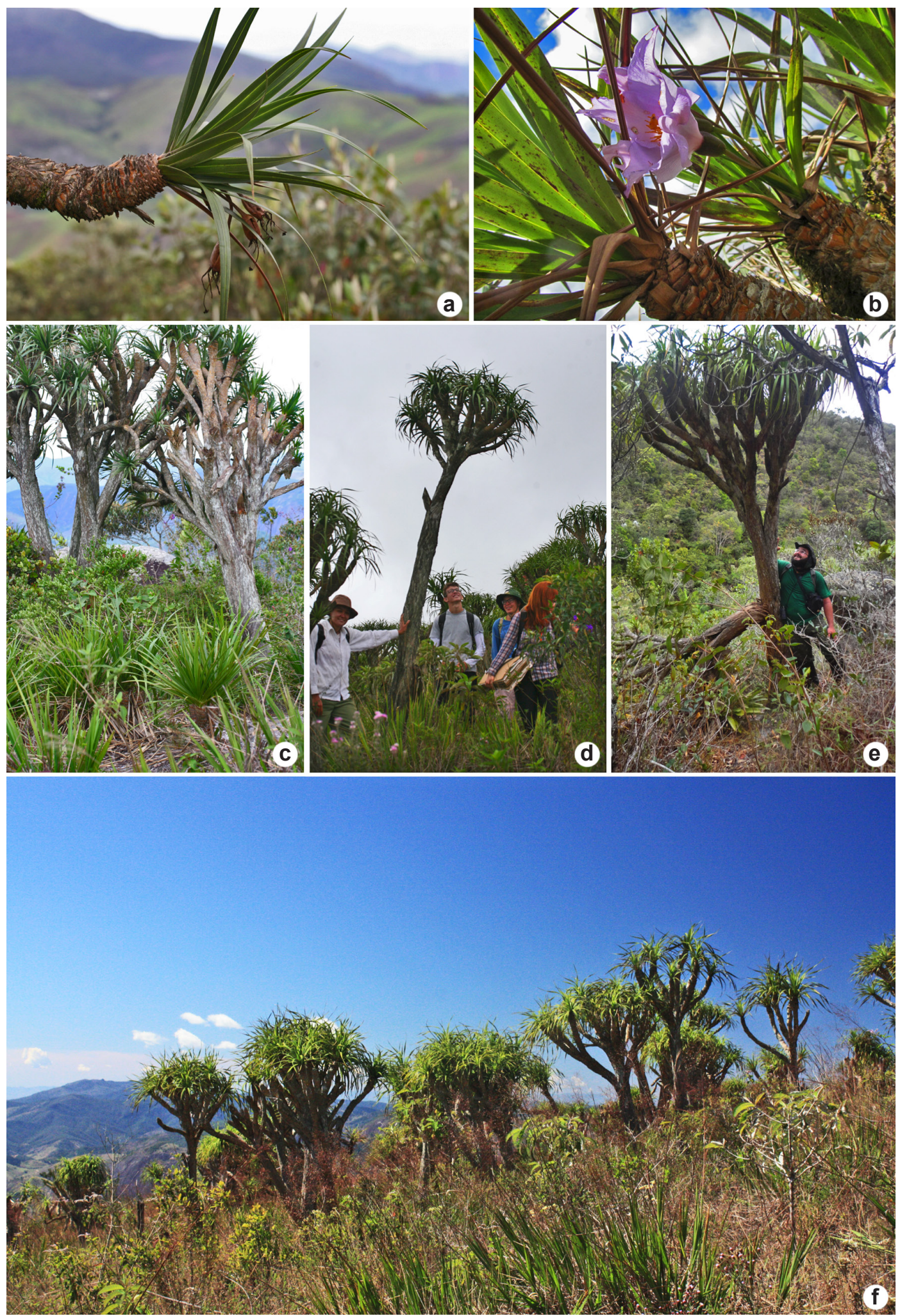

Figure 2 - Vellozia gigantea - a. stem with fruits; b. stem with flower; c. a population with adults in backgroung and seedlings in foreground; d. a 5,5-m tall individual in Serra do Padre Ângelo; e. a 5-m tall individual in Serra da Aliança; f. a population in Serra do Padre Ângelo. (a,c,d. by R. Mello-Silva; b. by D. Ribeiro; e. by M. Morais; f. by C. Siniscalchi). 
Leme EMC, Till W, Kollmann LJC, Moura RL \& Ribeiro OBC (2014) Miscellaneous new species of Brazilian Bromeliaceae - III. Phytotaxa 177: 61-100.

Loeuille BFP \& Pirani JR (2016) Two new syncephalous species of Eremanthus (Asteraceae: Vernonieae) from southeastern Brazil. Phytotaxa 243: 128-136.

Lopes LE, Marçal BF \& Chaves AV (2016) The patchy distribution of the Pale-throated Serra-Finch Embernagra longicauda (Aves: Thraupidae) in the eastern Brazilian mountaintops: the overlooked campos rupestres of the Rio Doce valley. NorthWestern Journal of Zoology 12: 373-376.

Lousada JM, Borba EL, Ribeiro KT, Ribeiro LC \& Lovato MB (2011) Genetic structure and variability of the endemic and vulnerable Vellozia gigantea (Velloziaceae) associated with the landscape in the Espinhaço Range, in southeastern Brazil: implications for conservation. Genetica 139: 431-440.

Meira RMSA, Peixoto AL, Coelho MAN, Ponzo APL, Esteves VGL, Silva MC, Câmara PEAS \& MeiraNeto JAA (2016) Brazil's mining code under attack: giant mining companies impose unprecedented risk to biodiversity. Biodiversity \& Conservation 25: 407-409.

Mello-Silva R (1991) The infra-familial taxonomic circumscription of the Velloziaceae. A historical and critical analysis. Taxon 40: 45-51.

Mello-Silva R \& Menezes NL (1999) Two new Brazilian Velloziaceae, Vellozia auriculata and Vellozia gigantea, and a key to the related dracenoid species of Vellozia. Novon 9: 536-541.

Miranda FEL (1999) Estudos em Laelia (Orchidaceae) - III. Bradea 8: 123-127.

Nalini Jr. HA, Machado R \& Bilal E (2005) Geoquímica e petrogênese da Suíte Galiléia: exemplo de magmatismo tipo-I metaluminoso pré-colisional neoproterozóico da região do médio vale do rio Doce (MG). Revista Brasileira de Geociências 35(supl.): 23-34.

Nazareno AG \& Vitule JRS (2016) Too many mining disasters in Brazil. Nature 531: 580.
Pirani JR, Mello-Silva R \& Giulietti AM (2003) Flora de Grão-Mogol, Minas Gerais, Brasil. Boletim de Botânica da Universidade de São Paulo 21: 1-24.

Prance GT (1994) The use of phytogeographic data for conservation planning. In: Forey PL, Humphries CJ \& Vane-Wright RI (eds.) Systematics and conservation evaluation. Systematics Association Special Vol. 50. Clarendon Press, Oxford. Pp. 145-163.

Saint-Hilaire AFCP (1830) Voyage dans les provinces de Rio de Janeiro et de Minas Geraes. Tome premier. Grimbert et Dorez, Paris. 458p.

Schwacke CAW (1898) Plantas novas mineiras. Vol. 1. Imprensa Official do Estado de Minas Gerais, Ouro Preto. 10p.

Silveira AA (1908) Flora e serras mineiras. Imprensa Official, Belo Horizonte. 206p.

Siniscalchi CM, Loeuille BFP \& Pirani JR (2016) A new species of Chresta (Vernonieae, Asteraceae) endemic to the Mata Atlântica Domain, Brazil. Phytotaxa 244: 80-88.

Strickland MA (1844) Descriptions of several new or imperfectly defined genera and species of birds. The Annals and Magazine of Natural History 86: 409-421.

The Guardian (2015) Brazil's mining tragedy: was it a preventable disaster? Available at <https:// www.theguardian.com/sustainable-business/2015/ nov/25/brazils-mining-tragedy-dam-preventabledisaster-samarco-vale-bhp-billiton>. Access on 6 January 2017

Van den Berg C (2008) New combinations in the genus Cattleya Lindl. (Orchidaceae). Neodiversity 3: 3-12.

Van den Berg C (2014) Reaching a compromise between conflicting nuclear and plastid phylogenetic trees: a new classification for the genus Cattleya (Epidendreae; Epidendroideae; Orchidaceae). Phytotaxa 186: 75-86.

Wied-Neuwied MAP (1820) Reise nach Brasilien in den Jahren 1815 bis 1817. Vol. 1. H.L. Brönner, Frankfurt am Main. 376p. 